\title{
Editors' Foreword
}

The need to enhance the study of Jewish attitudes towards death in their broadest aspects was recognized and discussed in 2007 by Simha Goldin and Stefan Reif. They decided to organize a conference, and set up an international steering committee composed of Andreas Lehnardt, Avriel Bar-Levav and Uri Ehrlich, as well as themselves, chaired by Stefan Reif.

The conference was held at the Cymbalista Jewish Heritage Center and the Lester and Sally Entin Faculty of Humanities of Tel Aviv University on 10-12 May 2010, with the aid of the Johannes Gutenberg University, Mainz, and under the auspices of the Goldstein-Goren Diaspora Research Center at Tel Aviv University. A total of twenty-two papers were delivered, in English and in Hebrew, the latter in the context of a Workshop devoted to 'Reading Gravestones as Texts', directed by Avriel Bar-Levav. The present volume represents the outcome of that conference, with some minor omissions and significant additions.

Frederick Paxton, whose keynote address provided the necessary background in the medieval Christian world for the whole topic of the conference, was also kind enough to respond favourably to the editors' request to append to his paper some comments on the texts of all the other presentations that are included here. This was greatly appreciated.

The editors wish to thank all those individuals and institutions who contributed to the success of the conference and the preparation of the volume, especially Sara Appel, Ora Azta and other staff at the GoldsteinGoren Diaspora Research Center. They are also grateful to Dvora Bregman and Menahem Schmelzer for reviewing the manuscript and to the Johannes Gutenberg University, Mainz, and to the Harry and Gertrude Landy Charitable Trust for their support. They would also like to express their thanks to Albrecht Döhnert for establishing the Rethinking Diaspora SubSeries at De Gruyter Publishing House, and to the editors of the Studia Judaica Series - Charlotte Fonrobert, Alexander Samely, and Günther Stemberger - for kindly accepting the volume as the first in the new SubSeries. 
